\title{
Evaluation of Optima Regional Health Information System with HOT-Fit on Technology Aspects Approach in Johar Baru Health Center Jakarta
}

\author{
Ahmad Fauzan ${ }^{1}$, Noviandi² ${ }^{*}$ (D) \\ 1. Department of Health Information Management Universitas Esa Unggul, Jakarta 11510, Indonesia \\ 2. Department of Informatics Engineering Universitas Esa Unggul, Jakarta 11510, Indonesia
}

\author{
ahmadfauzan.af.19@gmail.com \\ "noviandi@esaunggul.ac.id (coresponden author)
}

\section{ABSTRACT}

The Information technology development has affected various sectors, including health services. The several technologies have been used to improve health facilities performance. At Johar Baru Health center, central Jakarta, SIKDA (Sisitem Informasi Kesehatan Daerah) Optima application has been applied. Meanwhile, the implementation of SIKDA Optima is not as good as expected. There still many disruptions during the use of this application such a delay service and delivery of report was not in a real time, therefore an evaluation is needed. The purpose of this study was to determine the quality of system, information, and service which is affecting the satisfaction of SIKDA Optima users at Johar Baru Health Center, Central Jakarta. This study used a quantitative approach with observational survey and cross-sectional design. The population in this study was 98 persons and the sample were 79 users of SIKDA Optima, consist of 19 doctors, 22 nurses, 17 midwives, 9 pharmacies, 2 medical recorder and 10 administration staffs. Data analysis was performed using multiple linear regression. The results of multiple linear regression test showed that the user satisfaction of SIKDA Optima $=-3.832+0.549(\mathrm{KS})+0.757(\mathrm{KI})+0.359(\mathrm{KL})$ with a p-value of $\mathrm{KS} 0.001<0.05)$, $\mathrm{p}$-value $\mathrm{KI} 0,000<0,05)$, and the $\mathrm{p}$-value of $\mathrm{KL}$ is $0.009<0.05$. The conclusion of this study is the quality of system, information, and services that is used at Johar Baru Health Center have a significant influence on the satisfaction of SIKDA Optima users.

Keywords : Health services tecnology, SIKDA optima, hot fit.

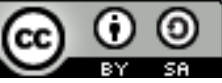




\section{INTRODUCTION}

The health information system (HIS) is an important aspect in supporting health development in Indonesia. According to Indonesian Government Regulation No. 46 of 2014, HIS is a set of structures that includes integrated data, information, indicators, procedures, tools, technology and human resources to direct actions or decisions that are beneficial to support health development (Indonesia, 2014).

The government by the ministry of health has developed HIS nationally which aims to provide useful information for decision making in carrying out each health program (Thenu et al., 2016). One of the developments of HIS in Indonesia is the Regional Health Information System or SIKDA. SIKDA was developed by health service unit nationally, or namely SIKDA generic. SIKDA generic can connect online and be integrated in all public health center or often called puskesmas, hospitals and other health facilities. However, the application of generic SIKDA in every puskesmas is considered unable to cover all needs, therefore each puskesmas optimizes SIKDA (SIKDA optima). More than that, SIKDA Optima needs to be evaluated, it is related to information needs that have an impact on the quality of data and production of information generated from existing information systems (Isnawati et al., 2016).

System evaluation methods have been widely reported including Technology Acceptance Model (TAM) (Kamal et al., 2020). Unified Theory of Acceptance and Use of Technology (UTAUT) (Anwar et al., 2012), Human, Organization and Technology-Fit (HOT-Fit) (Erlirianto et al., 2015), Performance, Information, Economics, Controls, Efficiency and Service (PIECES) (Tullah \& Hanafri, 2014), and many more in the fields of education, data retrieval and health information systems.

The TAM's evaluation method have advantages in evaluating systems, such as, seeing two aspects of perceived usefulness and perceived of use (Ayanlade et al., 2019), UTAUT of performance expectancy, effort expectancy, social influences, and facilitating conditions (Gunawan, 2018). Both methods only assess whether the system being evaluated is acceptable to the user, but it is not seen from the aspects of human, organization, technology and the benefits provided. HOT-Fit is a method used to measure these four aspects.

The HOT-Fit method is used to evaluate systems that have long been used. By (Sibuea et al., 2017) reported that evaluated a system that has been used for 8 years at a love group hospital. Data collected were analyzed quantitatively using multiple regression. The results of his research show the impact on system user satisfaction, positive influence of users on the system, positive user satisfaction on the quality of information produced, service quality, system quality on organizational structure, service quality on user satisfaction, system quality on organizational structure, service quality on organization and organizational environment to the organizational structure.

Report by (Jannah \& Salsabila, 2019), to evaluate SIKDA optima from the aspect of human resources (HR). From 79 samples of users who use SIKDA Optima from the HR aspect shows that there is a significant influence with the real benefit equation of $5.716-0.016$ system users +0.776 SIKDA Optima user satisfaction and system user satisfaction by $66.6 \%$.

In this research we use HOT-Fit is an evaluation method that can be used to measure four aspects of technology. Why? because based on two previous researchers Jannah and Putri who evaluated the system from the aspects of HR and the organization of the benefits.

\section{THE MATERIAL AND METHOD}

\subsection{Health Information System (HIS)}

The Health Information System (HIS) is a system that integrates data collection, processing, reporting and use of information to improve the effectiveness and efficiency of health services through better management at all levels of health (Susanto \& Sukakdi, 2011).

In achieving good health status, it is necessary to develop HIS. Integrated HIS by level of health services such as SIKNAS and SIKDA can help with good health.

\subsection{SIKDA}

The Sistem Informasi Kesehatan Daerah (SIKDA) is an information system that includes information systems developed in health service units (Puskesmas, Hospitals, Polyclinics, Private Practices, Pharmacies, Laboratories), District / City Health Office information systems, and Provincial Health Office information systems. The development of SIKDA, facilitation of its development is carried out by first helping regions reorganize their health systems and reformulate Health Management in Regional Health Systems (SKD). In this case cooperation forums will be developed both at the provincial level and at the district / city level. Afterwards, information, indicators and data needs as well as the information system are formulated (Isnawati et al., 2016). In this research, SIKDA are grouped according to their nature, namely generic SIKDA and SIKDA Optima.

\subsubsection{SIKDA Generic}

Generic SIKDA was developed in order to improve health services through the use of communication information technology. This application is the application of Health Information System standardization so that it is expected that data and information on health that is fast, precise and accurate are available by utilizing information and communication technology in decision making/policy in the health sector (RI, 2011) (Fig. 1). 


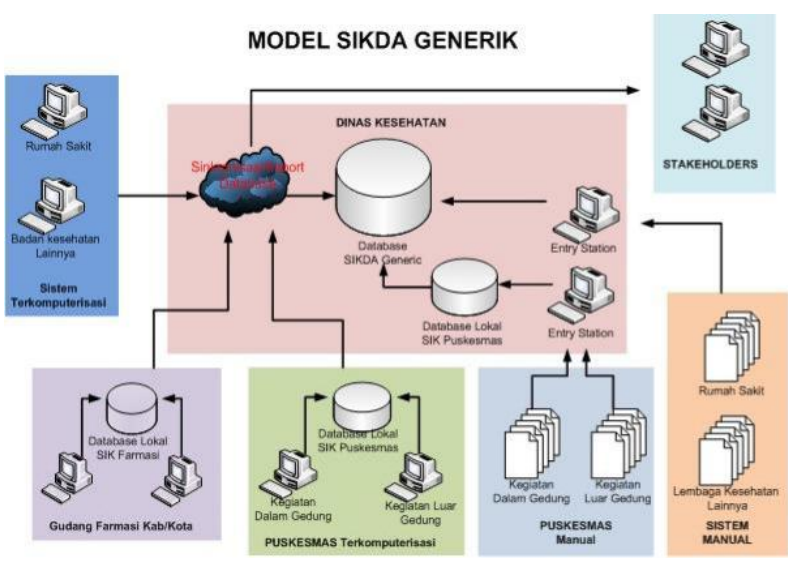

Fig. 1. Workflow of the SIKDA generic model.

\subsubsection{SIKDA Optima}

SIKDA Optima is a SIKDA generic that is optimized according to the needs of the puskesmas involving third parties, namely vendors. SIKDA generic is used to facilitate puskesmas staff when reporting to various programs within the Ministry of Health. The SIKDA Generik is expected to flow data from the lowest level to the central level to run smoothly, standardized, on time, and accurately as expected.

\subsection{HOT-Fit Model}

HOT-Fit is a system evaluation model that provides a new framework from the aspects of human, organization and technology. This framework is built based on the IS Success model and the IT organization Fit model (Yusof et al., 2006), see Fig. 2. The Important components such as human, organization and technology in the IS Success model will be discussed in the HOT-Fit model.

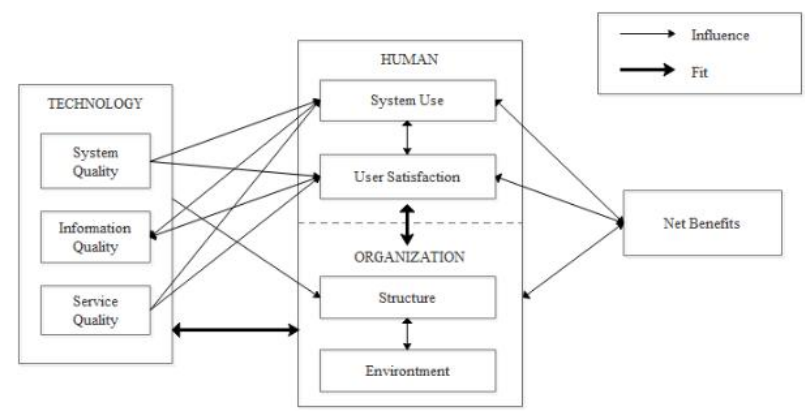

Fig. 2. Framework of the HOT-Fit model.

HOT-Fit models have been used successfully to identify factors, dimensions and measurement indicators, and able to identify the relationship and conceptual appropriateness of human, technological and organizational factors.

The human component is assessing an information system in terms of the system users, the level of its users, training, knowledge, expectations, and attitudes towards or against the system. In addition, this component also assesses the system from the aspect of user satisfaction. The organizational component evaluates the system from aspects of the structure and environment of the organization. The technology component consists of system quality, information quality and service quality (Hakam, 2016).

The variables and indicators used in this study are:

1) Technology as measured by the system quality

- system quality: user friendly system, completeness of the system (functionality or features), performance, and security;

- information quality: content usefulness;

- service quality: system response and technical support.

2) Net Benefit

- measured from the efficiency and effectiveness of the work;

- assist in decision making.

\subsection{Frame of Mind}

The influence factors of Net Benefit (benefits of SIKDA Optima) in the framework of thinking are only seen from the technological aspects that can affect the success of the SIKDA Optima application, see Fig. 3.

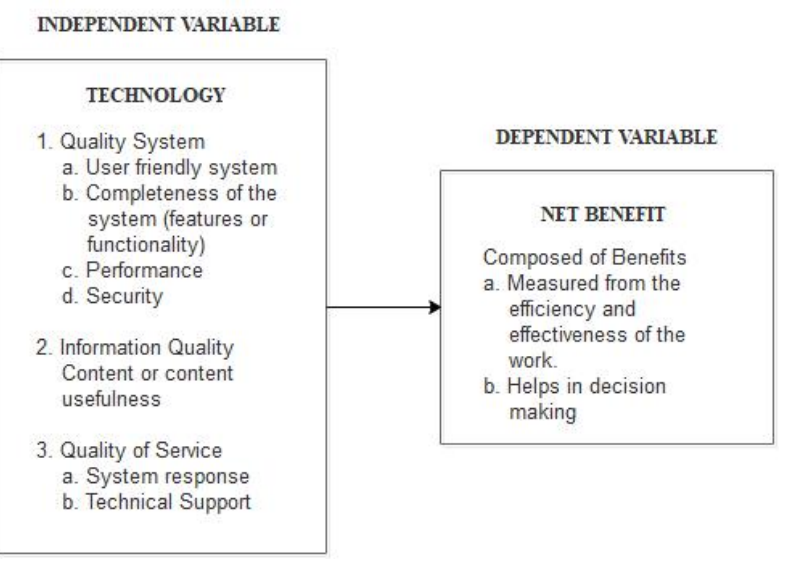

Fig. 3. The frame of mind of the proposed method

\subsection{Research Hypothesis}

Based on the model theory that has been described in

Fig. 3 can be drawn research hypotheses, as follows:

H1: There is an influence of the quality of the system (SIKDA optima) on the tangible benefits of SIKDA optima in the Johar Baru Health Center Area, Jakarta.

$\mathrm{H} 2$ : There is an influence of information quality on the real benefits of SIKDA Optima in the Johar Baru Health Center Area, Jakarta.

H3: There is an effect of service quality on the real benefits of SIKDA Optima in the Johar Baru Health Center Area, Jakarta

System evaluation using the HOT-Fit model was carried out in the Johar Baru I, II and III Puskesmas with a population of 98 SIKDA Optima users consisting of 
doctors, nurses, midwives, pharmacy, PMIK and admin. From the total population, determined the sample that will be used in this study. Determination of the sample using the slovin method (Singh \& Masuku, 2014).

$$
n=\frac{N}{1+N\left(e^{2}\right)}
$$

where

$$
\begin{aligned}
& N \text { : population } \\
& n: \text { sample } \\
& \text { e : error value. } \\
& \text { we use } 0,05 \text { as value of } \mathrm{p} \text {-value. }
\end{aligned}
$$

The number of samples we used based on Equation 1 is 79 users.

\subsection{Data Analysis}

There are two techniques used in this study, namely univariate analysis and multivariate analysis:

1) univariate analysis: this technique aims to explain each of the research variables. This analysis describes or describes the dependent variable (real benefit) and the independent variable (system usage and user satisfaction)

2) multivariate analysis: Multivariate analysis is used for processing a large number of variables which aim to find the effect of these variables on an object simultaneously or simultaneously. In this study multivariate analysis was used to determine the quality of the system, the quality of information and the quality of services to the real benefits (Net Benefits) of SIKDA Optima. The statistical test used in this study is multiple linear regression to measure the effect of more than one independent variable on the dependent variable.

$Y=a+b 1 \cdot x 1+b 2 \cdot x 2+b 3 x 3$

Where:
Y : Dependent variable
$\mathrm{X} 1$ : Independent variable (system quality)
$\mathrm{X} 2$ : Independent variable (information quality)
$\mathrm{X} 3$ : Independent variable (service quality)
a : Constants
b : Regression coefficients for each variable

\section{RESULT AND DISCUSSION}

\subsection{Costumer Satisfaction}

In Table 1 shows the satisfaction of SIKDA Optima users in the Johar Baru Health Center Area of Central Jakarta it is concluded that users are satisfied with SIKDA Optima is $39.24 \%$ and the number of users is 31 out of 79 users.

Based on questionnaire answers from 79 respondents who used SIKDA Optima obtained SIKDA user satisfaction results expressed satisfaction of $53.16 \%$ with satisfaction categories are:

1. SIKDA Optima is easy to use $(81.0 \%)$

2. SIKDA Optima helps in completing work $(81.0 \%)$

3. SIKDA Optima improves the works quality.

Table 1. Frequency distribution of information quality for
SIKDA Optima in Johar Baru health center area of central Jakarta in 2019.

\begin{tabular}{|c|c|c|}
\hline Costumer satisfaction & Total & $\mathbf{\%}$ \\
\hline Less satisfied & 15 & 18,99 \\
\hline Quite satisfied & 12 & 27,85 \\
\hline Satisfied & 31 & 39,24 \\
\hline Very satisfied & 11 & 13,92 \\
\hline
\end{tabular}

\subsection{System Quality}

The application of SIKDA Optima system in the Johar Baru Health Center Area, Central Jakarta is said to be good. It can be seen from 79 users, 47 users with $59.50 \%$ stated that the quality of the SIKDA Optima system is good (see, Table 2). Based on the results of the calculation of the score of user answers to the quality of the SIKDA Optima system shows that the average deviation of the sample is said to be good with an accuracy value of 2.305 and an average value of 16.09.

Table 2. Frequency distribution of system quality for SIKDA Optima in Johar Baru health center area of central Jakarta in 2019.

\begin{tabular}{|c|c|c|}
\hline System of quality & Total & $\mathbf{\%}$ \\
\hline Less & 16 & 20,25 \\
\hline Enough & 10 & 12,66 \\
\hline Well & 47 & 59,50 \\
\hline Very good & 6 & 7,59 \\
\hline
\end{tabular}

\subsection{Information Quality}

Table 3. Frequency distribution of information quality for SIKDA Optima in Johar Baru health center area of central Jakarta in 2019.

\begin{tabular}{|c|c|c|}
\hline System of quality & Total & \% \\
\hline Less & 9 & 11,39 \\
\hline Enough & 21 & 26,58 \\
\hline Well & 34 & 43,04 \\
\hline Very good & 15 & 18,99 \\
\hline
\end{tabular}

As you can see in Table 3, it shows the quality of Optima Information SIKDA in the Johar Baru Jakarta Health Center, which is $11.39 \%$ less, $26.58 \%$ sufficient, $43.04 \%$ good and $18.99 \%$ very good. So, it can be concluded that the information quality of SIKDA Optima in Johar Baru Health Center is already good in the application of SIKDA Optima.

The information quality generated by SIKDA Optima based on system users is good performance at $62.03 \%$ with three categories:

1. SIKDA Optima can be accounted for at $87.3 \%$

2. Information generated in accordance with the data entere in SIKDA Optima is $84.8 \%$

3. Ease to reading information is $83.5 \%$ 


\subsection{Service Quality}

Table 4. Frequency distribution of service quality for SIKDA Optima in Johar Baru health center area of central Jakarta in 2019.

\begin{tabular}{|c|c|c|}
\hline Service quality & Total & \% \\
\hline Less & 15 & 18,99 \\
\hline Enough & 24 & 30,38 \\
\hline Well & 30 & 37,97 \\
\hline Very good & 10 & 12,66 \\
\hline
\end{tabular}

As you can see in Table 4, that the quality of SIKDA Optima services in the Johar Baru Jakarta Health Center Area is in the good category, namely lacking (18.99\%), sufficient $(30.38 \%)$, good $(37.97 \%)$ and very good $(12.66 \%)$. It can be concluded that the quality of the SIKDA Optima services in the Johar Baru Health Center area is already good to apply.

According to the user's system that services quality that provided by SIKDA Optima is a good service that is equal to $50.63 \%$, where there are three evaluation criteria:

1. System can be accessed from anywhere is $72.2 \%$

2. Ease of guidance for user's system on is $67.1 \%$

3. IT team has good empathy attitude to helping user's system is $64.6 \%$

\subsection{Service Quality Influence of system quality,} information quality, and service quality to user satisfaction of SIKDA Optima systems

Normal P-P Plot of Regression Standardized Residual

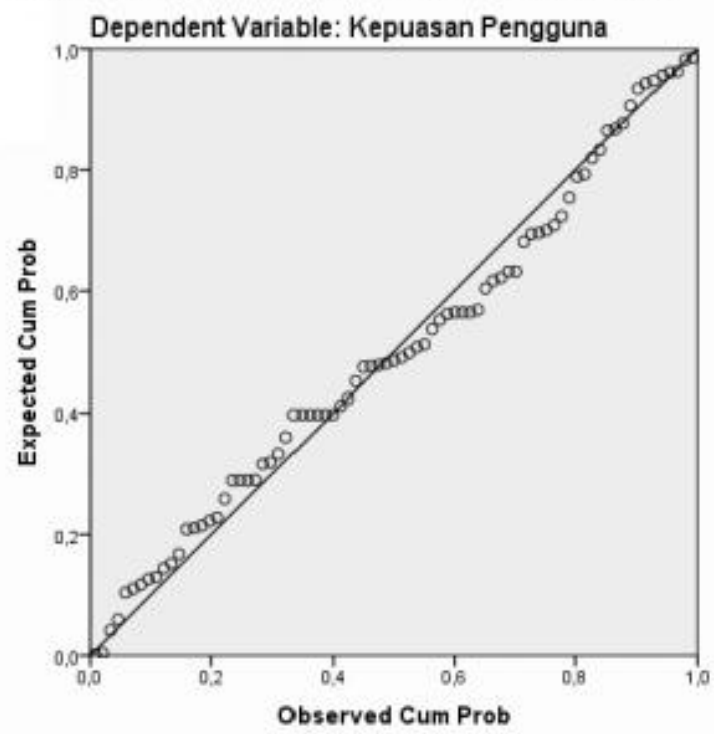

Fig. 4 Normal p-p plot of regression.

As you can see in Fig. 4 shows that the data distribution at the diagonal source satisfies the normality assumption or the resulting regression model is said to meet the normality assumption.

The value of user satisfaction in SIKDA Optima is 3,832 where the regression coefficient values are 0.549 ,
0.757 and 0.358 respectively. The results of multiple linear regression tests are $=-3,832+0,549(\mathrm{KS})+$ $0,757(\mathrm{KI})+0,359(\mathrm{KL})$.

Increasingly a system quality value (X1) will increase the value of user satisfaction. The $p$-value is $0.001<0.05$, so the quality of the system has a significant influence on user satisfaction. Increasing the value of information quality will increase the value of user satisfaction with a p-value of $0.00<0.05$ so that the information quality variable significantly influences user satisfaction. Service quality has a significant influence on user satisfaction with a $\mathrm{p}$-value of $0.09<0.05$.

The results of determination's coefficient indicate a significant effect between the variables of system quality, information quality, service quality on user satisfaction with R2 of 0.62 .

\section{CONCLUSION}

The SIKDA Optima user satisfaction in the Johar Baru Jakarta Health Center area was said to be satisfied by $53.16 \%$ and unsatisfied by $46.84 \%$ this is because the information generated was not accurate as needed (30.4\%), and SIKDA Optima was not in accordance with user expectations $(27.8 \%)$. In addition, the quality of the SIKDA Optima system in the Johar Baru Jakarta Health Center area was already said to be good at $67.09 \%$ and not good at $32.91 \%$ this is because the SIKDA Optima System experienced an error $(53.2 \%)$. The information quality category also showed a good performance of $62.03 \%$ and not good at $37.97 \%$, this is because the information generated by SIKDA Optima was incomplete and not detailed (29.1\%).

For service's quality by SIKDA Optima in Johar Baru Health Center Area of Central Jakarta also shows the best performance is good at $50.63 \%$ and not good at $49.37 \%$, this is because the user is not given a guarantee of quality and service by the IT (39.2\%).

The results of the study from the Simultaneous Test (Test F) are $0,000<0.005$, it can be concluded that this value indicates a significant influence between the quality of the information quality system and the quality of SIKDA Optima services to user satisfaction in the Johar Baru Health Center Area, Central Jakarta.

\section{REFERENCES}

Anwar, N., Masrek, M. N., \& Rambli, Y. R. (2012). Visitor Management system by applying the model of UTAUT. 2012 IEEE Symposium on Business, Engineering and Industrial Applications, 223-228. https://doi.org/10.1109/ISBEIA.2012.6422874

Ayanlade, O. S., Oyebisi, T. O., \& Kolawole, B. A. (2019). Health Information Technology Acceptance Framework for diabetes management. Heliyon, 5(5), e01735. https://doi.org/10.1016/j.heliyon.2019.e01735

Erlirianto, L. M., Ali, A. H. N., \& Herdiyanti, A. (2015). The Implementation of the Human, Organization, and Technology-Fit (HOT-Fit) Framework to Evaluate the Electronic Medical Record (EMR) 
System in a Hospital. Procedia Computer Science, 72 , https://doi.org/10.1016/j.procs.2015.12.166

Gunawan, H. (2018). Identifying Factors Affecting Smart City Adoption Using The Unified Theory of Acceptance and Use of Technology (UTAUT) Method. 2018 International Conference on Orange Technologies (ICOT), 1-4. https://doi.org/10.1109/ICOT.2018.8705803

Hakam, F. (2016). Analisis, Perancangan dan Evauasi Sistem Informasi kesehatan.

Indonesia, P. R. (2014). Peraturan Pemerintah Republik Indonesia Nomor 46 Tahun 2014 Tentang Sistem Informasi Kesehatan. www.depkes.go.id/download.php

Isnawati, K., Nugroho, E., \& Lazuardi, L. (2016). Implementasi Aplikasi Sistem Informasi Kesehatan Daerah ( SIKDA ) Generik Di UPT . Puskesmas Gambut Kabupaten. Journal of Information Systems for Public Health, 1(1), 64-71.

Jannah, L. M., \& Salsabila, S. (2019). Evaluasi Penerapan SIKDA Optima Dengan Pendekatan HOT-Fit pada Aspek Sumber Daya Manusia di Wilayah Puskesmas Johar Baru Jakarta Pusat. Indonesian of Health Information Management Journal, 7(1), 16-21.

Kamal, S. A., Shafiq, M., \& Kakria, P. (2020). Investigating acceptance of telemedicine services through an extended technology acceptance model (TAM). Technology in Society, 60(February), 101212 .

https://doi.org/10.1016/j.techsoc.2019.101212

RI, K. K. (2011). SIKDA Generik. Buletin Jendela Data dan Informasi Kesehatan Triwulan III ISSN 2088$270 X$.

Sibuea, G. H. C., Napitupulu, T. A., \& Condrobimo, A. R. (2017). An evaluation of information system using HOT-FIT model: A case study of a hospital information system. 2017 International Conference on Information Management and Technology (ICIMTech), 106-111. https://doi.org/10.1109/ICIMTech.2017.8273520

Singh, A., \& Masuku, M. (2014). Sampling Techniques \& Determination of Sample Size in Applied Statistics Research: an Overview. Ijecm.Co.Uk, II(11), 1-22. http://ijecm.co.uk/wpcontent/uploads/2014/11/21131.pdf

Susanto, G., \& Sukakdi. (2011). Sistem Informasi Rekam Medis Pada Rumah Sakit Umum Daerah (RSUD) Pacitan Berbasis Web Base. Journal Speed - Sentra Penelitian Engineering Dan Edukasi, 3(4), 18-24.

Thenu, V. J., Sediyono, E., \& Purnami, C. T. (2016). Evaluation of Health Center Management Information System to Support the Implementation of Generic SIKDA using HOT (fit) method in District of Purworejo. Jurnal Manajemen Kesehatan Indonesia, 4(2), 129-138. https://doi.org/10.14710/JMKI.4.2.2016.129-138

Tullah, R., \& Hanafri, M. I. (2014). Evaluasi Penerapan Sistem Informasi Pada Politeknik LP3I Jakarta Dengan Metode Pieces. Jurnal Sisfotek Global, 4(1), 22-28.

journal.stmikglobal.ac.id/index.php/sisfotek/article/ download $/ 36 / 37$

Yusof, M. M., Paul, R. J., \& Stergioulas, L. K. (2006). Towards a Framework for Health Information Systems Evaluation. Proceedings of the 39th Annual Hawaii International Conference on System Sciences (HICSS'06), 95a-95a. https://doi.org/10.1109/HICSS.2006.491 